\title{
Comparison between the irrigation qualities of conventional tertiary and UF + RO advanced treated wastewaters
}

\author{
Abdallah Abusam $^{1 *}$, Bader Al-Anzi \\ ${ }^{1}$ Water Resource Division, Water Technologies Department, Kuwait Institute for Scientific Research, Safat, Kuwait; \\ *Corresponding Author: abusam3a@yahoo.com \\ ${ }^{2}$ Environmental Technology Department and Management, College for Women, Kuwait University, Safat, Kuwait.
}

Received 9 September 2011; revised 18 October 2011; accepted 28 October 2011.

\begin{abstract}
The Ultrafiltration and Reverse Osmosis (UF + RO) membrane system is nowadays frequently used in wastewater reclamation. The almost complete removal of the dissolved elements, however, raises concerns about the suitability of the water treated by this system for agricultural irrigation. This study compared the irrigation qualities of UF + RO permeate and conventional tertiary effluent, using the WHO guidelines. Obtained results indicated slight to moderate degrees of restrictions are required for the reuse of the tertiary effluent as agricultural irrigation water, while no restrictions are needed for the UF + RO permeate. But it had also been found that the UF + RO system unnecessarily deprive the reclaimed water from nutrients and organic matters, which would have been recycled beneficially through agricultural irrigation.
\end{abstract}

Keywords: Wastewater; Reclamation; Reuse; Tertiary Effluent; UF + RO Permeate

\section{INTRODUCTION}

Water scarcity is the main reason for the increasing trend in wastewater reuse in agriculture worldwide. Especially in arid and semi arid regions, where water resources are very limited, wastewater reuse has become the most attractive option to alleviate pressure on freshwater resources. Wastewater reuse has generally proven to be economically and environmentally beneficial [1]. Advantages of wastewater reuse include reduction of the amount of freshwater extracted from the environment, provision of a reliable supply of large amounts of water, enhancement of crop productivity and reduction of environmental degradation [1-3]. However, potential prob- lems related to wastewater reuse are risks from pathogenic microorganisms, increased soil salinity due to high total dissolved solids (TDS) concentrations, clogging of soils and/or irrigation systems with suspended solids [4], and introduction of toxics to crops and crop consumers (trace elements, e.g. Na, B and Se and toxic compounds, e.g. endocrine disrupters and pharmaceuticals) [5]. Therefore, a reclaimed wastewater that will be reused as agricultural irrigation water should satisfy certain quality requirements, e.g. the Food and Agriculture Organization $(\mathrm{FAO})$ proposed quality requirements [6].

Wastewater is conventionally treated up to a seconddary level (i.e., biological treatment plus chlorination) or to a tertiary level (i.e., biological treatment plus sand filtration and chlorination). Usually, secondary and tertiary treatments result in a limited removal of dissolved salts and toxic compounds, and therefore, they are commonly not considered to meet the requirements for unrestricted irrigation. For this reason the use of membrane systems for advanced treatment of wastewater has recently received great attention [7].

Membrane systems are frequently used in the reclamation of wastewater in order to produce high quality water for e.g. agricultural irrigation, industrial uses and aquifer recharge applications [8]. Membranes used in water and wastewater treatment can be classified, based on the pore size, into four categories: Microfiltration (MF), Ultrafiltration (UF), Nanofiltration (NF) and Reverse Osmosis (RO) membranes [9]. For polishing the secondary effluent, a two-stage membrane system that consists of UF + RO membranes is commonly used. Here the function of the UF is to remove organic matter and pathogens, while the function of the RO is to remove dissolved solids [10]. Due to the very high removal efficiency, however, there are concerns that conventional UF + RO treatment may deprive the reclaimed water from plant essential nutrients [11]. The objective 
of this study was to compare the irrigation quality of a tertiary effluent to wastewater treated to advanced level using UF + RO membrane system.

\section{MUNICIPAL WASTEWATER TREATMENT AND REUSE IN KUWAIT}

Kuwait municipal wastewater is treated to tertiary or advanced levels at four main activated sludge plants, located in Jahra, Riqqa, Sulaibiya and Um-Al-Haiman areas. Sulaibiya plant is the world's largest membranebased reclamation plant, which was originally built for providing an alternative source to potable water for $\mathrm{Ku}$ wait [12]. But its effluent is used since commissioning in December 2004 in agricultural and landscape irrigations. Sulaibiya plant treats wastewater up to UF and RO advanced levels. The other three plants (Jahra, Riqqa and Umm-Al-Haiman plants) are all conventional activated sludge plants that treat wastewater to tertiary levels (biological treatment plus sand filtration and chlorinetion). Table 1 gives the basic technical information about the main municipal wastewater treatment plants in Kuwait.

The effluents of only Jahra (tertiary) and Sulaibiya (RO permeate) plants are pumped to a central facility, called the Data Monitoring Center (DMC), located about $30 \mathrm{~km}$ from Kuwait city, where treated wastewater is stored, further chlorinated and distributed to the main farming areas situated in Abdalli, Sulaibiya and Wafra areas. Effluents of the other plants are reused mainly onsite or to irrigate greeneries near the motorways.

The DMC facility has six effluent storage reservoirs (ESRs) of total capacity equal to $340,000 \mathrm{~m}^{3}$, pump houses, chlorination units, a laboratory for water analysis and a computerized data management facility for recording the daily quantity and quality of the ESRs inflows and outflows. Storage of treated wastewater effluents in properly designed and operated ESR's improves the effluent quality, particularly with respect to concentrations of nutrients and trace metals [13], and thus help in producing high crop yields [14].

\section{MATERIALS AND METHODS}

Data used in this study were obtained from the records of the DMC facility in Kuwait. DMC daily-records contain information about the quantity and quality of in- and outflow of the ESRs. In this study only the data for the year 2005 were used. During 2005, the average inflows from Sulaibiya and Jahra plants were $331,367 \mathrm{~m}^{3} / \mathrm{d}$ and $25,805 \mathrm{~m}^{3} / \mathrm{d}$, respectively. Thus, the average hydraulic residence time at the ESRs was 25.5 hours, while the average mixing ratio (Jahra stream/Sulaibiya stream) was 0.08 (ranged from 0.03 to 0.14 ).

Collected daily data about the treated wastewater quantity and quality was summarized and statistically analyzed. Wastewater quality parameters were actually determined at the DMC laboratory in accordance with the American standard methods for water and wastewater examination [15], except for the $\mathrm{EC}$ and $\mathrm{pH}$ which were determined in the field using portable measuring devices. Solids (TSS, TDS and VSS) were determined by gravimetric method. COD was determined by standard open reflux method. $\mathrm{BOD}_{5}$ was found after five days incubation at $20^{\circ} \mathrm{C}$. Hach spectrophotometers were used to measure $\mathrm{NO}_{4}, \mathrm{PO}_{4}$ and $\mathrm{SO}_{4}$ while $\mathrm{NH}_{4}$ and org-N were determined by distillation and digestion methods. $\mathrm{Na}, \mathrm{Ca}$ and heavy metals were measured using a flame atomic adsorption spectrophotometer (ASS).

Quality parameters of Jahra tertiary effluent and Sulaibiya RO permeate were assessed for agricultural irrigation and compared, using criteria adopted from the WHO guidelines [5] given in Tables 2 and 3. The criteria consisted of $\mathrm{pH}, \mathrm{EC}$, TDS, TSS, SAR, Cl, Na, Ca, $\mathrm{Mg}, \mathrm{B}, \mathrm{HCO}_{3}$ and $\mathrm{TN}$ (Table 2) plus ten trace elements (Table 3). SAR was calculated as follows:

$$
S A R=\frac{\mathrm{Na}^{+}}{\sqrt{\frac{\mathrm{Ca}^{2+}+\mathrm{Mg}^{2+}}{2}}}
$$

where $\mathrm{Na}^{+}, \mathrm{Ca}^{2+}$ and $\mathrm{Mg}^{2+}$ are in meq/l.

Table 1. Kuwait's municipal wastewater treatment plants.

\begin{tabular}{|c|c|c|c|}
\hline Plant & Secondary Treatment & Tertiary Treatment & Advanced Treatment \\
\hline $\begin{array}{c}\text { Jahra } \\
\left(70,000 \mathrm{~m}^{3} / \mathrm{d}\right)\end{array}$ & $\begin{array}{l}6 \text { conventional activated-sludge systems operated } \\
\text { in extended aeration mode. }\end{array}$ & Sand filtration + chlorination & - \\
\hline $\begin{array}{c}\text { Riqqa } \\
\left(120,000 \mathrm{~m}^{3} / \mathrm{d}\right)\end{array}$ & $\begin{array}{l}12 \text { conventional Activated-sludge systems operated } \\
\text { in extended aeration mode. }\end{array}$ & Sand filtration + chlorination & - \\
\hline $\begin{array}{l}\text { Sulaibiya } \\
\left(420,000 \mathrm{~m}^{3} / \mathrm{d}\right)\end{array}$ & 9 BNR activated-sludge systems. & - & $\begin{array}{l}\text { Disc filtration }+\mathrm{UF} \\
+\mathrm{RO}+\text { chlorination }\end{array}$ \\
\hline $\begin{array}{l}\text { Umm-Al-Haiman } \\
\qquad\left(20,000 \mathrm{~m}^{3} / \mathrm{d}\right)\end{array}$ & 4 oxidation ditch systems. & $\begin{array}{l}\text { Sand filtration }+ \text { UV } \\
+ \text { chlorination }\end{array}$ & - \\
\hline
\end{tabular}




\section{RESULTS AND DISCUSSION}

The measured qualities of Jahra tertiary effluent and Sulaibiya RO permeate are summarized in Table 4. The following sections discuss the irrigation qualities of the two steams, based on the criteria presented in Tables 2 and 3.

\section{1. $\mathrm{pH}$}

Irrigation water with low $\mathrm{pH}(<6.5)$ promotes leaching of heavy metals, while irrigation with water which has high $\mathrm{pH}(>11)$ destroys bacteria and can also temporarily inhibit movement of heavy metals. The WHO recommends the $\mathrm{pH}$ values of the irrigation water to be in the range of $6.5-8.0$. In general, $\mathrm{pH}$ outside this recommended range can cause a nutritional imbalance or may contain a toxic ion, and thus, negatively affecting plant growth $[6,16]$. The measured $\mathrm{pH}$ values ranged from 6.5 - $7.3($ mean $=7.1)$ and $7.2-7.4($ mean $=7.3)$ for Jahra tertiary effluent and Sulaibiya RO permeate, respectively (Table 4). This implies that both Jahra and Sulaibiya effluents satisfy the WHO recommendation with respect to $\mathrm{pH}$ values.

\subsection{Salinity Hazards}

In contrast to drinking water $(\mathrm{EC}<0.7$, TDS $<500$ $\mathrm{mg} / \mathrm{l}$ ), treated wastewater is generally characterized by high salinity due to addition of salts from domestic and industrial sources. High salinity can damage soil, plants, crops and groundwater [5]. EC and TDS are good indicators of salinity hazards to crops. Table 4 shows that EC and TDS concentrations in Jahra tertiary effluent $(\mathrm{EC}=1.7 \mathrm{dS} / \mathrm{m}, \mathrm{TDS}=932 \mathrm{mg} / \mathrm{l})$, are much higher than that of Sulaibiya RO permeate $(\mathrm{EC}=0.17$, TDS $=88.4)$. Although EC in the range of 0.75 to $2.25 \mu \mathrm{S} / \mathrm{m}$ (similar to that of Jahra effluent) is widely used [17], irrigation with water that has EC closer to $2.0 \mu \mathrm{S} / \mathrm{m}$ can be a longterm health hazard to animals and humans [18]. According to WHO guidelines (Table 3), slight to moderate restrictions should be applied when irrigating with Jahra tertiary effluent, while none is required when irrigating with Sulaibiya RO permeate. Main restrictions that should be applied in such a case are selection of salt tolerant crops and application of appropriate salinity control measures.

Table 2. Guidelines for interpretation of water quality for irrigation (Adopted from [5]).

\begin{tabular}{|c|c|c|c|c|}
\hline \multirow{2}{*}{ Potential Irrigation Problem } & \multirow{2}{*}{ Unit } & \multicolumn{3}{|c|}{ Degree of Restriction } \\
\hline & & None & Slight to Moderate & Severe \\
\hline EC & $\mu \mathrm{S} / \mathrm{m}$ & $<0.7$ & $0.7-3.0$ & $>3.0$ \\
\hline TDS & $\mathrm{mg} / 1$ & $<450$ & $450-2000$ & $>2000$ \\
\hline TSS & $\mathrm{mg} / 1$ & $<50$ & $50-100$ & $>100$ \\
\hline $\mathrm{EC}$ at $\mathrm{SAR}=0-3$ & $\mathrm{dS} / \mathrm{m}$ & $>0.7$ & $0.7-0.2$ & $<0.2$ \\
\hline $\mathrm{EC}$ at $\mathrm{SAR}=3-6$ & $\mathrm{dS} / \mathrm{m}$ & $>1.2$ & $1.2-0.3$ & $<0.3$ \\
\hline $\mathrm{EC}$ at $\mathrm{SAR}=6-12$ & $\mathrm{dS} / \mathrm{m}$ & $>1.9$ & $1.9-0.5$ & $>0.5$ \\
\hline $\mathrm{EC}$ at $\mathrm{SAR}=12-20$ & $\mathrm{dS} / \mathrm{m}$ & $>2.9$ & $2.9-1.3$ & $<1.3$ \\
\hline $\mathrm{EC}$ at $\mathrm{SAR}=20-40$ & $\mathrm{dS} / \mathrm{m}$ & $>5.0$ & $5.0-2.9$ & $<2.9$ \\
\hline Sodium $\left(\mathrm{Na}^{+}\right)$: Sprinkler Irrigation & $\mathrm{meq} / 1$ & $<3$ & $3-9$ & $>9$ \\
\hline Chloride $\left(\mathrm{Cl}^{-}\right)$: Sprinkler Irrigation & meq/1 & $<3$ & $>3$ & \\
\hline Chloride $\left(\mathrm{Cl}^{-}\right)$: Surface Irrigation & $\mathrm{meq} / 1$ & $<4$ & $4-10$ & $>10$ \\
\hline Bicarbonate $\left(\mathrm{HCO}_{3}\right)$ & $\mathrm{mg} / \mathrm{l}$ & $<90$ & $90-500$ & $>500$ \\
\hline Total Nitrogen (TN) & $\mathrm{mg} / \mathrm{l}$ & $<5$ & $5-30$ & $>30$ \\
\hline $\mathrm{pH}$ & - & & Normal range: $6.5-8.0$ & \\
\hline
\end{tabular}

Table 3. WHO recommended maximum concentration for trace elements [6].

\begin{tabular}{cc}
\hline Element & Recommended Maximum Concentrations (mg/l) \\
\hline $\mathrm{Al}$ & 5.0 \\
$\mathrm{Cd}$ & 0.01 \\
$\mathrm{Cr}$ & 0.10 \\
$\mathrm{Co}$ & 0.05 \\
$\mathrm{Cu}$ & 0.20 \\
$\mathrm{Fe}$ & 1.0 \\
$\mathrm{~Pb}$ & 5.0 \\
$\mathrm{Mn}$ & 0.20 \\
$\mathrm{Ni}$ & 0.20 \\
$\mathrm{Zn}$ & 2.0 \\
\hline
\end{tabular}


Table 4. Measured quality of Jahra tertiary effluent and Sulaibiya RO permeate.

\begin{tabular}{|c|c|c|c|c|}
\hline \multirow{2}{*}{ Parameter } & \multicolumn{2}{|c|}{ Jahra Tertiary Effluent } & \multicolumn{2}{|c|}{ Sulaibiya RO Permeate } \\
\hline & Range & Mean & Range & Mean \\
\hline $\mathrm{pH}(-)$ & $6.5-7.3$ & $7.1 \pm 0.3$ & $7.2-7.4$ & $7.3 \pm 0.1$ \\
\hline $\mathrm{EC}(\mathrm{dS} / \mathrm{m})$ & $1.1-2.1$ & $1.7 \pm 0.4$ & $0.04-0.35$ & $0.17 \pm 0.13$ \\
\hline TDS (mg/l) & $70-1380$ & $932 \pm 437$ & $13-209$ & $88.4 \pm 77.5$ \\
\hline TSS (mg/l) & $3-10.3$ & $8.0 \pm 2.9$ & $0.8-3.2$ & $1.9 \pm 1.0$ \\
\hline $\mathrm{SAR}(\mathrm{meq} / \mathrm{l})^{1 / 2}$ & $0.9-4.7$ & $2.9 \pm 1.5$ & $0.2-23.3$ & $5.2 \pm 0.3$ \\
\hline $\mathrm{Ca}^{2+}(\mathrm{mg} / \mathrm{l})$ & $18.1-31.9$ & $23.5 \pm 5.1$ & $0-2.2$ & $1.0 \pm 0.1$ \\
\hline $\mathrm{Mg}^{2+}(\mathrm{mg} / \mathrm{l})$ & $1.7-34.2$ & $16.5 \pm 3.0$ & $0-10.4$ & $10.4 \pm 2.8$ \\
\hline $\mathrm{Na}^{+}(\mathrm{mg} / \mathrm{l})$ & $42.6-114.4$ & $92.5 \pm 29.6$ & $0.6-14.4$ & $5.9 \pm 0.5$ \\
\hline $\mathrm{COD}(\mathrm{mg} / \mathrm{l})$ & $16.3-26.6$ & $22.5 \pm 3.7$ & $1.3-6.3$ & $3.0 \pm 0.18$ \\
\hline $\mathrm{BOD}_{5}(\mathrm{mg} / \mathrm{l})$ & $0-8.5$ & $5.0 \pm 2.6$ & $3-6.3$ & $4.7 \pm 1.4$ \\
\hline $\mathrm{Cl}^{-}(\mathrm{mg} / \mathrm{l})$ & $256-824$ & $397.7 \pm 191.4$ & $8-51$ & $27.9 \pm 1.9$ \\
\hline $\mathrm{B}(\mathrm{mg} / \mathrm{l})$ & $0.06-0.35$ & $0.14 \pm 0.01$ & $0.02-0.11$ & $0.06 \pm 0.01$ \\
\hline $\mathrm{HCO}_{3}(\mathrm{mg} / \mathrm{l})$ & $78-139$ & $110.3 \pm 23.4$ & $1-34$ & $24.5 \pm 11.0$ \\
\hline $\mathrm{TN}(\mathrm{mg} / \mathrm{l})$ & $4.1-9.8$ & $6.0 \pm 2.4$ & $0.6-5.8$ & $1.8 \pm 0.2$ \\
\hline $\mathrm{PO}_{4}(\mathrm{mg} / \mathrm{l})$ & $3.5-5.8$ & $5.0 \pm 0.9$ & $0.8-3.7$ & $1.9 \pm 0.1$ \\
\hline $\mathrm{Al}(\mathrm{mg} / \mathrm{l})$ & $0.0001-0.3357$ & $0.0600 \pm 0.1226$ & $0.0001-0.2211$ & $0.0983 \pm 0.01$ \\
\hline $\mathrm{Cd}(\mathrm{mg} / \mathrm{l})$ & $0.0001-0.0107$ & $0.0066 \pm 0.0033$ & $0.0004-0.4880$ & $0.0648 \pm 0.02$ \\
\hline $\mathrm{Cr}(\mathrm{mg} / \mathrm{l})$ & $0.0001-0.1126$ & $0.0200 \pm 0.0041$ & $0.0001-0.0667$ & $0.0099 \pm 0.002$ \\
\hline Co (mg/l) & $0.0001-0.0115$ & $0.0020 \pm 0.0003$ & $0.0001-0.0476$ & $0.0109 \pm 0.002$ \\
\hline $\mathrm{Cu}(\mathrm{mg} / \mathrm{l})$ & $0.0001-0.0114$ & $0.0066 \pm 0.0037$ & $0.0008-0.0122$ & $0.0045 \pm 0.0004$ \\
\hline $\mathrm{Fe}(\mathrm{mg} / \mathrm{l})$ & $0.0006-0.0019$ & $0.0012 \pm 0.0006$ & $0.0003-00013$ & $0.0008 \pm 0.0001$ \\
\hline $\mathrm{Pb}(\mathrm{mg} / \mathrm{l})$ & $0.0100-0.1068$ & $0.0523 \pm 0.0369$ & $0.0036-0.1063$ & $0.0467 \pm 0.0367$ \\
\hline $\mathrm{Mn}(\mathrm{mg} / \mathrm{l})$ & $0.0080-0.0291$ & $0.0163 \pm 0.0079$ & $0.0002-0.0054$ & $10.4 \pm 0.0015$ \\
\hline $\mathrm{Ni}(\mathrm{mg} / \mathrm{l})$ & $0.0001-0.0055$ & $0.0025 \pm 0.0003$ & $0.0001-0.0229$ & $0.0040 \pm 0.001$ \\
\hline $\mathrm{Zn}(\mathrm{mg} / \mathrm{l})$ & $0.0252-0.0677$ & $0.0413 \pm 0.0161$ & $0.0023-0.0216$ & $0.0138 \pm 0.006$ \\
\hline
\end{tabular}

\subsection{Total Suspended Solids}

Suspended solids present in irrigation water can be organic matters (e.g. plants, algae, bacteria), and/or inorganic matters (clay, sand, silt). High suspended solids concentration in irrigation water may cause a number of problems e.g. clogging of the irrigation systems, sealing of the soil surface, filling the voids between sand particles, reducing soil infiltration and drainage capability and increasing soil compaction. According to the WHO standards, total suspended solid (TSS) less than $50 \mathrm{mg} / 1$ is safe for a drip irrigation system, while values above $100 \mathrm{mg} / \mathrm{l}$ can cause plugging. Table 4 shows that TSS of Jahra tertiary effluent is in the range of $3-10.3 \mathrm{mg} / \mathrm{l}$ $($ mean $=8)$, while that of Sulaibiya RO permeate is in the range of $0.8-3.2 \mathrm{mg} / \mathrm{l}($ mean $=1.9)$. This indicates that TSS of both the tertiary and RO effluents are satisfying the WHO standards.

\subsection{Sodium, Calcium and Magnesium Hazards (SAR)}

Sodium content is an important criterion for evaluating irrigation water quality. Excessive amount of sodium can lead to development of alkaline soil and conesquently to reduction of soil permeability. At high concentration, sodium ion can replace the adsorbed calcium and magnesium ions, leading soil destruction. High concentration of sodium can also reduce the plant capability to absorb nutrient potassium and magnesium [19]. In addition, high concentrations of sodium may also cause injury to leaves [20]. The WHO guidelines [6] recommend no restriction at sodium concentration less than 3 $\mathrm{meq} / \mathrm{l}$ and slight to moderate degree of restriction at sodium concentration in the range $3-9 \mathrm{meq} / \mathrm{l}$, but severe restriction at sodium concentration greater than $9 \mathrm{meq} / \mathrm{l}$. Table 4 shows that sodium concentration of Jahra terti- 
ary effluent and Suliabiya RO permeate varied between 42.6 - $113.4 \mathrm{mg} / \mathrm{l}(1.85$ - $4.93 \mathrm{meq} / \mathrm{l})$ and $0.6-14.4 \mathrm{mg} / \mathrm{l}$ (0.03 - $0.63 \mathrm{meq} / \mathrm{l})$, respectively. Therefore, no degree of restriction is required when irrigating with Suliabiya RO permeate, while a slight to moderate degree of restriction is required when irrigating with Jahra tertiary effluent.

Possible future sodium damage to soil is commonly measured in terms of the Sodium Adsorption Ratio (SAR). SAR expresses better the exchangeable sodium percentages in the soil than only sodium percentage [21]. As shown in Table 4, calculated values of SAR were between $0.9-4.7$ and $0.2-23.3$, for Jahra tertiary effluent and Sulaibiya RO permeate, respectively, when EC values were in the range $1.1-2.1$ and $0.04-0.35$, respectively. According to the WHO guidelines (Table 2), thus, only a slight to moderate degree of restriction is required when irrigating with Jahra tertiary effluent, while none is require when irrigating with Sulaibiya RO permeate.

\subsection{Chloride}

Because it is usually not absorbed by soil and thus it moves in the transpiration stream and accumulates in the leaves, high chloride concentrations in the irrigation water can cause leaf burning or dying of leaf tissues. As shown in Table 4, the chloride concentration of Jahra tertiary effluent was in the range of $256-824 \mathrm{mg} / 1$ (7.2 $23.2 \mathrm{meq} / \mathrm{l})$ and that of Suliabiya RO effluent was 8 - 51 $\mathrm{mg} / \mathrm{l}(0.2$ - $1.4 \mathrm{meq} / \mathrm{l})$. According to the WHO guidelines presented in Table 3, a slight to moderate degree of restriction is therefore required when irrigating with Jahra tertiary effluent, while no degree of restriction is required when reusing Sulaibiya RO permeate.

\subsection{Boron}

Boron is an essential micronutrient for plant growth. Although boron can affect sensitive crops (e.g. ornamental plants), it does not affect soil [5]. Boron concentration in Jahra tertiary effluent varied between 0.06 $0.35 \mathrm{mg} / \mathrm{l}($ mean $=0.14)$, while that of Sulaibiya RO permeate was in the range of $0.02-0.11$ (mean $=0.06$ ) (Table 4). As the WHO guidelines [6] do not recommend any restriction for boron concentration less than $0.7 \mathrm{mg} / \mathrm{l}$, therefore, no degree of restriction is required when irrigating with Jahra tertiary effluent nor with Sulaibiya RO permeate.

\subsection{Total Nitrogen}

Nitrogen is an essential macronutrient for plants. It is usually found in wastewater in the forms of ammonia, nitrite, nitrate and organic forms of nitrogen. Total nitrogen (TN) is the sum of these forms of nitrogen. TN concentration of the Jahra tertiary effluent was in the range of $4.1-9.8 \mathrm{mg} / \mathrm{l}($ mean $=5.0)$, while $\mathrm{TN}$ concentration of Sulaibiya RO permeate was 0.6 - $5.8 \mathrm{mg} / \mathrm{l}$ $($ mean $=1.8)$ (Table 4). Notice that TN of Sulaibiya RO permeate $($ mean $=1.8)$ is much less than that of Jahra tertiary effluent (mean $=5.0$ ). That is, RO treatment had unnecessarily deprived the Sulaibiya reclaimed water from nitrogen, which is an essential plant macronutrient. According to the WHO guidelines (Table 2), no degree of restriction is required for irrigation with water with $\mathrm{TN}$ less than $<5 \mathrm{mg} / \mathrm{l}$, while a slight to moderate degree of restriction of required for irrigation water with $\mathrm{TN}$ between 5 - $30 \mathrm{mg} / \mathrm{l}$. Generally, TN less than $30 \mathrm{mg} / \mathrm{l}$ does not harm plants, except sensitive crops such as sugar beets [6]. Therefore, only a slight to moderate degree of restriction is required when irrigating using Jahra tertiary effluent for irrigation, while none is required when reusing Sulaibiya RO permeate.

\subsection{Heavy Metals}

Irrigation with water which contains high concentrations of heavy metals can lead to metal accumulation in both soils and crops, which consequently will cause health problems to crop consumers. Heavy metals are usually not absorbed by plants unless they reach the threshold concentrations [5]. Comparison of heavy metals concentrations given in Table 4 to the WHO recommended maximum levels (Table 3) clearly indicates that concentrations of heavy metals in Jahra tertiary effluent are far below the recommended maximum levels. Similarly, heavy metals concentrations in Sulaibiya RO permeate are also less than the recommended maximum level, except few instances of high cadmium concentration $(0.4880 \mathrm{mg} / \mathrm{l}$ while the recommended maximum is 0.01). [5]. Usually, common wastewater treatment processes remove most of heavy metal concentrations [22] as demonstrated by the results obtained for Jahra tertiary effluent (Table 4).

\subsection{Organic Matter}

Organic content of wastewater usually increases soil moisture, retain metals and enhances microbial activity. Therefore, irrigation with wastewater is better than adding synthetic fertilizers [6]. Irrigation with even extremely high organic matter concentration (BOD > $500 \mathrm{mg} / \mathrm{l}$ ) usually does not impact negatively the environment. Table 4 shows that COD of Jahra tertiary effluent was in the range of $16.3-26.6 \mathrm{mg} / \mathrm{l}($ mean $=22.5)$, while that of Sulaibiya RO permeate was in the range of $1.3-6.3$ $\mathrm{mg} / \mathrm{l}(\mathrm{mean}=3.0)$. Notice also here how unnecessarily RO treatment had removed almost all the organic matter content from Sulaibiya wastewater. In contrast, all BOD 
of Jahra tertiary effluent can be reused beneficially in agriculture and without any adverse environmental impact.

\subsection{Phosphorus}

Phosphorus is also a plant macronutrient. Normally wastewater does not contain large amounts of phosphorus that can impact negatively the environment. Further, irrigation with high concentrations of phosphorus and for a long term does not damage the environment [6]. Table 4 shows that measured $\mathrm{PO}_{4}$ values were in the range of $3.5-5.8 \mathrm{mg} / \mathrm{l}($ mean $=5.0)$ and $0.8-3.7 \mathrm{mg} / \mathrm{l}$ $($ mean $=1.9)$ for Jahra tertiary effluent and Sulaibiya RO permeate, respectively. Also notice here that, RO treatment had without a need removed most of the phosphorus, which would have been beneficially recycled through agricultural irrigation reuse.

\section{CONCLUSIONS}

Based on the results of this study, the following conclusions could be made:

- According to the WHO guidelines [6], no degree of restriction is required when irrigating with Sulaibiya RO permeate, while only slight to moderate degrees of restrictions are required when irrigating with Jahra tertiary effluent, with respect to salinity hazards and to high concentrations of sodium and chloride.

- RO treatment, however, removes unnecessarily nitrogen, phosphorus and organic matter from the reclaimed wastewater.

\section{ACKNOWLEDGEMENTS}

Data used in this study were collected during the execution of a project entitled "Development of Wastewater Quality Database and Assessment of Effluent Quality for Potential Reuse in Kuwait (WT013C)" at KISR. This project was partially financed by the Kuwait Foundation for the Advancement of Sciences (KFAS).

\section{REFERENCES}

[1] Layson, A. and Sorgini, L. (2007) Low-pressure membranes help solve water scarcity. Water, 34, 34-36.

[2] Sheikh, B., Jaques, R.S. and Cort, R.P. (1987) Reuse of municipal wastewater effluent for irrigation of raw-eaten food crops: A five year field study. Desalination, 67, 245-254.

[3] Chakrabarti, C. (1995) Residual effect of long-term land application of domestic wastewater. Environmental International, 21, 333-339. doi:10.1016/0160-4120(95)00021-C

[4] Toze, S. (2006) Reuse of effluent water: Benefits and risks. Agricultural Water Management, 80, 146-159. doi:10.1016/j.agwat.2005.07.010
[5] WHO (2006) Guidelines for the safe use of wastewater, excreta and grey water. Wastewater Use in Agriculture, 2, World Health Organization, Lyon.

[6] Ayers, R.S. and Westcot, D.W. (1985) Water quality for agriculture. FAO Irrigation and Drainage, Paper 29, Food and Agriculture Organization, Rome.

[7] Oron, G., Gillerman, L., Bick, A., Buriakovsky, N., Manor, Y., Ben-Yatshak, E., Katz, L. and Hagin, J. (2006) A two stage membrane treatment of secondary effluent for unrestricted reuse and sustainable agricultural production. Desalination, 187, 335-345. doi:10.1016/j.desal.2005.04.092

[8] Schaefer, J. (2001) Reliable water supply by reusing wastewater after membrane treatment. Desalination, 138, 91-92. doi:10.1016/S0011-9164(01)00249-1

[9] Frenkel, V.S. (2008) Membrane in water and wastewater treatment. Proceedings of the World Environmental and Water Resources Congress, 2008, 316-324.

[10] Oron, G., Gillerman, L., Buriakovsky, N., Bick, A., Gargir, M., Dolan, Y., Manor, Y., Katz, L. and Hagin, J. (2008) Membrane technology for advanced wastewater reclamation for sustainable agriculture production. Desalination, 218, 170-180. doi:10.1016/i.desal.2006.09.033

[11] Abusam, A. and Shahalam, A. (2010) Comparative assessment of advanced membrane treatment of municipal wastewater for reuse in Kuwait. Desalination and Water Treatment, 13, 254-258. doi:10.5004/dwt.2010.1096

[12] Gagne, D. (2004) Sulaibiya water reuse project begins full operations. Water and Wastewater International, 19, 19-21.

[13] Mancini, G., Barone, C., Roccaro, P. and Vagliasindi, F.G.A. (2007) The beneficial effects of storage on the quality of wastewater for irrigation: A case study in Sicily. Water Science and Technology, 55, 417-424. doi:10.2166/wst.2007.042

[14] Barbagallo, S., Cirelli, G. L., Consoli, S. and Somma, F. (2003) Wastewater quality improvement through storage: A case study in Sicily. Water Science and Technology, 47, 169-176.

[15] APHA (1998) Standard methods for examination of water and wastewater. 20th Edition, American Public Health Association, Washington, DC.

[16] Pescod, M.B. (1985) Wastewater treatment and use in agriculture. Irrigation and Drainage Paper No. 47, FAO, Rome.

[17] Alobaidy, A.H.M.J., AL-Sameraiy, M.A., Kadhem, A.J. and Abdul-Majeed, A. (2010) Evaluation of treated municipal wastewater quality for irrigation. Journal of Environmental Protection, 1, 216-225. doi:10.4236/jep.2010.13026

[18] Forth, H.D. (1984) Fundamentals of soils science. 7th Edition, John Wiley and Sons, New York.

[19] Harussie, Y., Rom, D., Galil, N. and Semiat, R. (2001) Evaluation of membrane processes to reduce the salinity of reclaimed wastewater. Desalination, 137, 71-89. doi:10.1016/S0011-9164(01)00206-5

[20] Begum, S. and Rasul, M.G. (2009) Reuse of stormwater for watering gardens and plants using green gully-A new stormwater quality improvement device (SQID). Water Air Soil Pollution: Focus, 9, 371-380. doi:10.1007/s11267-009-9226-x 
[21] Tiwari, T.N. and Manzoor, A. (1988) Pollution of subarnarekha river near Jamshedpur and the suitability of its water for irrigation. Indian Journal of Environmental Protection, 8, 494-497.
[22] Shiekh, B., Jaques, R.S. and Cort, R.P. (1987) Reuse of tertiary municipal wastewater effluent for irrigation of raw eaten food crops: A 5 year study. Desalination, 67, 245-254. 